\title{
VÁLLALKOZÓI ÖKOSZISZTÉMA VIZSGÁLATA DEBRECENBEN A NYITOTT INNOVÁCIÓS TEREK SZEMSZÖGÉBÖL
}

\author{
Oláh Judit - Horváth Adrienn
}

\section{SUMMARY}

Innovation is not just a technology, but it is rather a comprehensive vision of what the future should look like and which requires changes in many ambits. Innovation is driven by people's needs, ambitions and dreams, and it is necessary that people at different positions in the society change the way they work and live. Innovation, as a result of human interactions, often fails because people do not understand each other, as they belong to different worlds which have their own languages and cultures. While innovation system-like thinking recognizes that the needs are a good mix of factors for innovation, it is hard to establish the perfect mix beforehand: innovation systems and policies need to be adaptive. We tried to bring this complex vision to our future. The actuality of the topic is provided by the fact that we are in the period of the development of digital industrial revolution, on the peak of the technology innovations, slowly resulting in the revolutions of the machines.

\section{BEVEZETÉS}

Az Európai Unió versenyképessége a kutatás-fejlesztés és az innováció (KFI) területén - globális léptékben nézve - hosszabb ideje visszaesést mutat. Európában az elmúlt évtizedben a KFI - benne különösen a $\mathrm{K}+\mathrm{F}$ - területi és strukturális különbségei tovább növekedtek. Az úgynevezett európai paradoxon, vagyis az, az ellentmondás, hogy amíg Európában kiváló tudományos eredmények születnek, addig a gyakorlati innovációs teljesítmények ennél jóval szerényebbek. Természetesen mindezek hatásai Kelet-Közép-Európában és Magyarországon is jelentkeznek. Ezért is figyelemre méltó, hogy a fejlett európai uniós országok többsége és az Európai Unió egésze, a világgazdasági válság ellenére, törekszik a $\mathrm{K}+\mathrm{F}$ támogatások növelésére. A KFI három főbb probléma területe mutatkozik Magyarországon: a tudásbázisok, a tudásteremtés gyengeségei; a tudásáramlás (technológia-transzfer, egyéb transzfermechanizmusok hiányosságai); a tudásfelhasználás. Az Európai Unió 2014 és 2020 közötti időszakra vonatkozó K+F célú keretprogramja, vagyis a Horizont 2020 stratégia, az uniós szinten elérhető $\mathrm{K}+\mathrm{F}$ célú források jelentős növelését tüzte ki céljául (Nemzetgazdasági Minisztérium 2013).

Az innovációs folyamat, illetve ennek tudományos megközelítése is alapvető átalakuláson ment keresztül az elmúlt években. A Henry Chesbrough 2003-ban megjelent könyvét követően általánosan elfogadottá vált egy új fogalom, az úgynevezett nyílt innováció (Open Innovation). Sok vállalat a nyílt innováció tevékenysége során: belső és külső forrásokat összevonva arra törekszik, hogy a szellemi tulajdonban rejlö gazdasági értéket minél jobban kihasználja. Egy mondattal, a nyílt innováció a tudás be- és kiáramlásának célzott felhasználása a belső innováció felgyorsítására, és a piacok kibővítése az innováció külső alkalmazására (Molnár-Németh 2009). 
A nyílt innovációs tér ennek értelmében, egy olyan tér, ahol a tudás be- és kiáramlásának célzott felhasználása történik, a belső innováció felgyorsítására, és a külső innováció felhasználására, ahol elkötelezett tenni akaró emberek, tudásukat és ötleteiket bővíthetik, kicserélhetik. A jelenlegi gazdasági helyzetben, valamint az oktatás és a munka világa közötti kapcsolat miatt nagyon fontos, hogy milyen ismeretekkel rendelkeznek a végzett diákok a szakmájukkal, az elhelyezkedéssel kapcsolatban (Oláh-Hutóczki 2012). Az Impact HUB (továbbiakban HUB) egy fajtája, a nyitott innovációs tereknek.

A kutatás célja egy nyitott innovációs térként müködő HUB létrehozásának vizsgálata Debrecenben, mely a már meglévő létező innovációs tereken túl valami újat adhat. Ennek alapot képezhet, az Európai Unió erre irányuló KFI stratégiája, és ez Debrecen 2014. évi város gazdaságfejlesztési tervével is összhangba hozható. Egy ilyen innovatív hídképző tér kialakításának gyakorlati szempontból is fontos hatása lehet a régión gazdaságának élénkítésében.

\section{TÉMAFELVETÉS}

Az elmúlt évtizedek is bebizonyították a világgazdasági verseny ma már nemcsak gazdasági tömbök és országok, hanem ennél alacsonyabb térségi szinten, a régiók szintjén is egyre élesebbé válik. Ebben a versenyben pedig hátrányt jelent, ha Európában a tudáshoz való hozzáférés területileg korlátozottabb, mint az Egyesült Államok vagy Ázsia gazdaságaiban. Európa nem mondhat le arról, hogy a helyi sajátosságoknak és a komparatív előnyöknek megfelelően minden régióban létrejöjjön a kutatás-fejlesztési és innovációs képességek kritikus tömege. A fejlesztési források növekedése és összehangolása mellett az új tervezési időszakban mind nemzeti, mind pedig közösségi szinten új típusú kormányzati beavatkozások is várhatóak. Európai Unió a következő periódusban a versenyképességet támogató szakpolitikák terén egy új rendezö elvet is elötérbe állít: a régiók intelligens - vagy a tartalmat pontosabban visszaadó szóhasználattal élve ésszerü és hatékony - szakosodását (smart specialisation) (Nemzetgazdasági Minisztérium 2013). A létrehozáskor az Európai Unió ezen irányú törekvését érdemes szem elött kell tartani. A Nemzeti Innovációs Rendszer (National Innovation System, NIS) komplex összefüggései, a nemzetgazdaságoknak a tudományos-müszaki haladást előmozdító, az innovációk terjedési sebességét determináló jellemzői állnak. Az OECD különösen nagy erőket fordított e rendszerek megismerésére is. A vizsgálódások szerint az innovációs folyamatokban elsősorban a tudományos szféra, a vállalatok, valamint, a két intézmény-csoport közt közvetítő tanácsadó intézmények tevékenysége jelentős, de számos további intézmény is szerepet kaphat (OECD 2007).

A Nemzeti Innovációs Rendszer múködésében, az innovációs tudás létrehozása, alkalmazása és terjedése a legfontosabb folyamatok. A Nemzeti Innovációs Rendszer múködési koncepcióját már tovább finomították, $\mathrm{s}$ az úgy nevezett Triple Hélix (Állam - Egyetem - Ipari/Üzleti) vagy a Nyugaton már müködő Quadro Hélix (Állam - Egyetem - Ipari/Üzleti - Civil szektor) modellek alkalmazásának fontosságára hívják fel a figyelmet (Pakucs et al. 2006). De már a legújabb 
Pentagonal Hélix modell is napvilágot látott melyben az én, mint emberek és felhasználók is szerepet kaptak. A kutatás a Triple Hélix modellre épült a kutatáshoz szükséges szakértők kiválasztásakor.

A HUB-ot 2005-ben alapították Londonban, azzal a céllal, hogy kialakítsanak egy ösztönzésre teret adó helyet, melynek célja, hogy összekösse és képessé tegye, azon embereket, akik vállalkozói ötleteket akarnak véghezvinni, a fenntartható befolyás érdekében. Az ötlet egyszerü, hiszen van elegendő olyan ember, aki rendelkezik egy jó ötlettel, egy jobb világért.

A HUB megalkotása elött az alapítók, ötleteket kölcsönöztek a legjobb laborokból, start-up inkubátoroktól, azért, hogy egy olyan tanuló és tudásközpontú helyet alkossanak, ahol egyedi társadalmi innovációs ökoszisztémát építhetnek. Egy hely, ahol minden szükséges eszköz, és körítés megvan, ami kell ahhoz, hogy nőjön és fejlődjön egy új vállalkozás a fenntartható fejlődésért, azzal a feltétellel, hogy, az alapítók gondoskodnak átadni, a jó tapasztalatokat, a megfelelő tudást, a kapcsolatokat, pénzt, és információkat a piacról. Mindezek mellett, a hely alkalmas legyen találkozókra, inspirálódásra és különböző emberek, különböző ötleteinek cserélésére is. Ezt a müködési elvet szemlélteti az alábbi 1. ábra, mely a teljes HUB Network minden tagja elfogad, és betart"(HUB GmbH 2012)

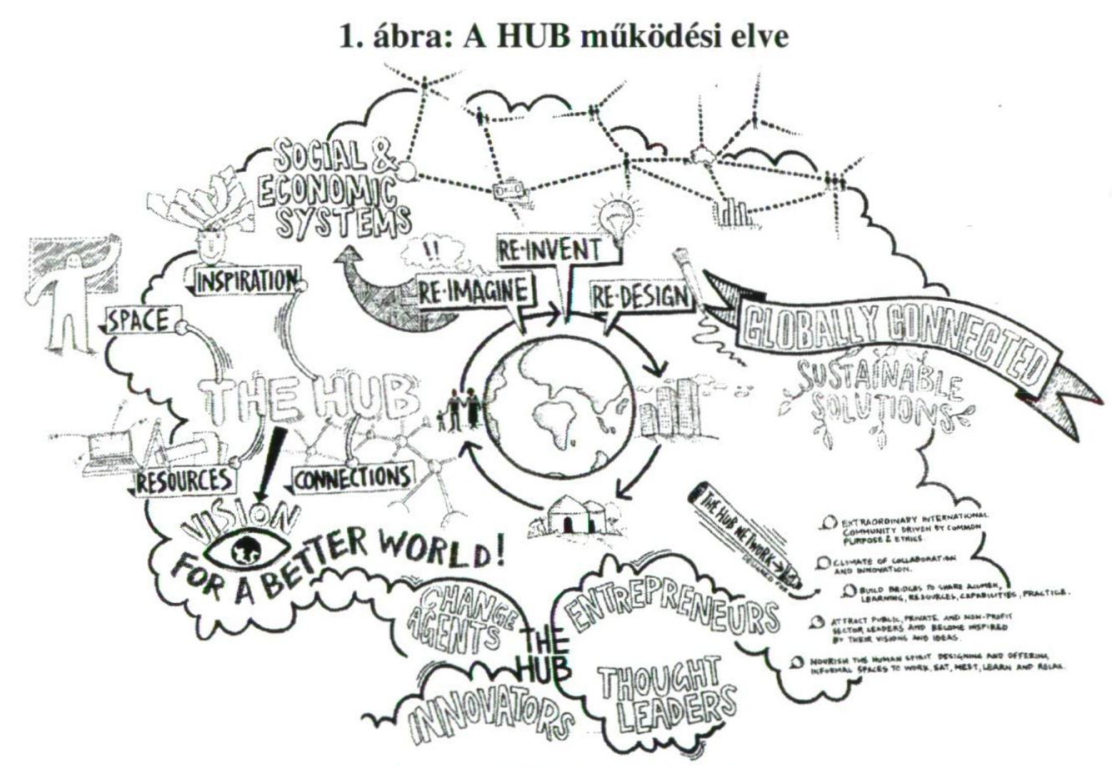

Forrás: HUB GmbH, 2012

A HUB alakításának ötlete futótűzként terjedt szerte a világon, felbukkanása 5 kontinensen átívelő globális mozgalmat eredményezett. 2012 októberéig, több mint 30 HUB-ot nyitottak, és mára már talán sokkal többet is számlál, egészen Londontól Melbourne-ig, Johannesburgtól Sao Pauloig és San Franciscotól Szingapúrig találkozhatunk HUB-al. Lehetőséget ad, hogy egy adott városban megfelelő, gyarapodó „,impact creatorok” (hatást kreálók) közössége alakuljon ki. 
Alapítása, egy hosszú távú (legalább 5-10 év), megegyezésen nyugszik, és ez idő alatt a HUB Network teljesen elkötelezödést vár el a rendszer tagjaitól.

Tulajdonképpen egy fizikai, virtuális vagy szociális hely, annak érdekében, hogy rálássunk a világ változásaira. Az újdonság varázsa talán abban rejlik, hogy mindenki igényeit képes kiszolgálni és globális hálózatot teremteni. Hiszen aki irodát bérelne és dolgozna, vagy aki csak egy-egy alkalommal egy asztalt, vagy a céges iratait tárolná, vagy virtuálisan néhány információ megszerzés erejéig használná a rendszert, annak is van lehetősége, mindezt úgy, hogy 5 kontinens bárhol a HUB Networkön belül megteheti, aki a HUB Network tagja.

A hely és a közösség is azért van, hogy segítse materializálni a világ változásait, azáltal, hogy felajánl egy egyedi infrastruktúra, kapcsolatok, inspiráció, és tanulás együttest.

HUB 3 eltérő elemből áll össze:

- Vibráló közösség: szenvedélyes, vállalkozó szellemü emberek, akik megosztják az alaptörekvést, s elöidéznek pozitív változást.

- Inspiráció forrása: ez biztosítja a tartalmat, azáltal, hogy gondolat elöremozdító eseményeket, innovációs laborokat, tanuló helyeket, inkubációt és témabeszélgetéseket nyújt.

- Inspiráló hely: ami rugalmas és magasan funkcionáló infrastruktúrát ad a munkához, találkozáshoz, tanuláshoz és a kapcsolatépítéshez.

\section{A VIZSGÁlat MÓDSZERE}

A vizsgálat célja, egy Debrecenben müködő Impact HUB létrehozása. A nemzetközi HUB Network által elöírt létrehozási menet egyik pontja egy város potenciálját felmérő megvalósíthatósági tanulmány készítése. A kutatás ennek a megvalósíthatósági tanulmánynak egy elő fázisa.

A nyitott innovációs térre vonatkozó, primer kutatás Delphi kérdőíves módszerrel zajlott. A Delphi módszert az USA-ban dolgozták ki az 1950-es években, hogy segítségével feltárják a tudomány fejlődésének jövőbeni fö irányvonalait, a várhatóan bekövetkező eseményeket és azok feltételezhető időpontját. A módszer lényege: az adott témában jártas szakemberek többfordulós megkérdezése, a szakértői csoport átlagvéleményének illetve az eltérő véleményeknek az elemzése. Az egyes fordulók során kapott eredmények visszacsatolásával a szakértők információt kapnak a szakmai közösség álláspontjáról, és ennek ismeretében lehetőségük van véleményük korrekciójára. A kérdőívek megalkotása egy probléma fókuszában van, vagy egy lehetőség, megoldás vagy elörejelzés fókuszában. A Delphinek két változata létezik egy kérdőíves és egy konferencia változata. Kutatásunk során kérdőíves megkérdezési formát alkalmaztunk (Turoff-Linstone 2002).

A Delphi kérdőív kitöltéséhez a szakértők kiválasztása a Hélix modellre épült. A szakértők a kormányzati, egyetemi, vállalkozói és civil szektorból kerültek ki. 
A kérdőív összeállításakor két nagyobb témában került sor a szakértők megkérdezésére.

- A HUB-ról általánosságban.

- HUB Debrecen szemszögéből.

Az 1. táblázat szemlélteti a két témakör kérdéseit.

\section{1. táblázat: A Delphi szakértői kérdőív kérdéssorának vázlatos bemutatása}

\begin{tabular}{|c|c|}
\hline HUB-ról általánosságban & HUB Debrecen szems \\
\hline $\begin{array}{l}\text { Ebben a kérdéscsoportban többek } \\
\text { között a szakértők ismereteit, } \\
\text { véleményét akartuk megtudni a } \\
\text { témával kapcsolatosan. Illetve a } \\
\text { figyelmet felkelteni a kutatási } \\
\text { témámra. Ilyen kérdésekre keresetem a } \\
\text { választ, mint például: } \\
\text { - Mit jelent számukra a HUB? } \\
\text { - Hogyan értelmezik? } \\
\text { - Milyen befolyásoló tényezőket } \\
\text { tartanak fontosnak a HUB } \\
\text { kialakulásakor? } \\
\text { - Elfogadják-e a kialakult } \\
\text { véleményeket? } \\
\text { - Egyet tudtak-e érteni a HUB } \\
\text { Network által állított } \\
\text { szabályokkal? }\end{array}$ & $\begin{array}{l}\text { Célzottan Debrecenre irányultak a } \\
\text { kérdéseink, hogy a Network által } \\
\text { előírt feltételeket hogyan és miként } \\
\text { látják a szakértők. Megvalósítható-e a } \\
\text { HUB vagy sem? Illetve, hogy } \\
\text { mennyire keltette fel az } \\
\text { érdeklödésüket a HUB? } \\
\text { - Ha lehetősége lenne, nyitna-e } \\
\text { HUB-ot? } \\
\text { - Csatlakozna-e a közösséghez, ha } \\
\text { létrejönne? } \\
\text { - Van-e valamilyen veszélye, hogy } \\
\text { létrejöjjön? } \\
\text { - Milyen elvárásokat támasztani az } \\
\text { alapítókkal és használókkal } \\
\text { szemben? } \\
\text { Milyen szektorok számára tenné } \\
\text { nyitottá a HUB-ot? }\end{array}$ \\
\hline
\end{tabular}

Forrás: Saját szerkesztés, 2013

\section{A VIZSGÁLAT EREDMÉNYEI}

A megvalósítás szempontjából fontosnak tartottuk megvizsgálni azokat a tényezőket, hogy kik vagy mik lehetnek a legfontosabb befolyásoló tényezök a létrejöttékor, hiszen a cél a jövőbeni megvalósítás. A kérdések megalkotásakor figyelembe vettük a különféle innovációs intézmények, ökoszisztémák befolyásoló tényezőit is, illetve a HUB Network által felállított elvárásokat is. A következőkben az ezekre a kérdésekre adott válaszok kerülnek bemutatásra.

A kik befolyásoló tényezőkön belül 3 nagy csoportot különböztettünk meg: intézmények, vállalkozások, civil szektor. Ennek eredmény mutatja be a 2. ábra. 


\section{2. ábra: A HUB létrejöttének befolyásoló tényezői a HUB alkotásakor Debrecenben}

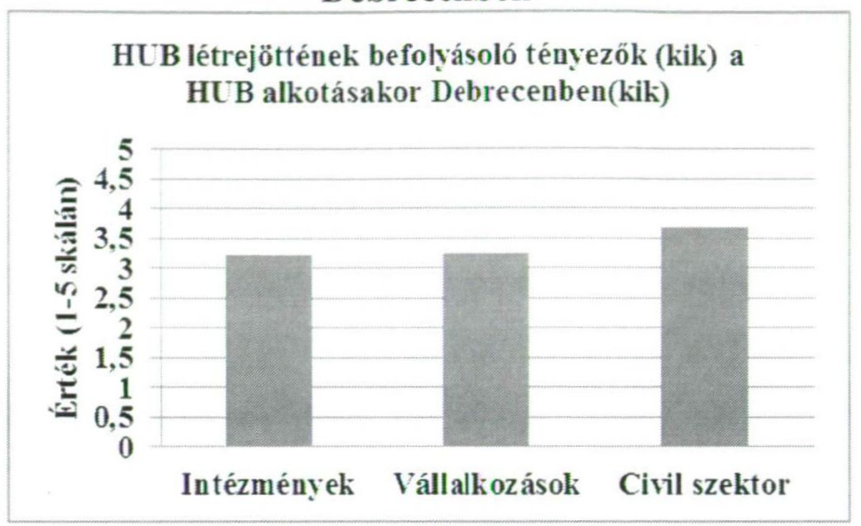

Forrás: Saját forrás, 2013

A válaszadók szerint a legmegfontosabb befolyásoló tényező a HUB megalkotásakor a civil szektor volt. Az eredmény meglepő, talán annak köszönhető mindez, hogy a civil szektor tartalmazta az alapító/alapítók személyeit, a használókat és a vásárlókat is, a civil szervezetek képviselöi és a közösségi helyiségek üzemeltetői mellett. Egy közösségi munkatér kialakításakor a civil szféra szerepe igen fontos.

A szakértői kérdőívet, - a kérdőív célja a vélemények összegyüjtése a lehetséges döntéshozó, és megvalósító személyektől az ötlet megvalósításáról - kiegészítetve követte, egy a piac igényeinek szükebb felmérése. Hiszen az alapítók és müködtetők személye után a legfontosabb a használók, a tagok, az ő igényeik kielégítése. A piac szükebb igény felmérése egy néhány már meglévő civil alkotó közösség (kb. 20-30 fö) tagjai előtt tartott ismertető előadásból és egy rövid kreatív workshop módszer megvalósításából állt. Ennek célja kettős volt, egyrészt az ötlet megismertetése, és véleményezése, másrészt az igények felmérése és ezeknek megvalósítási lehetőségei.

Bár a szakértők és a piac pozitív válaszai sem biztosítják egyértelmüen azt, hogy az Impact HUB müködése sikeres lenne 5-10 éven át. A további vizsgálat, és minél több információ megszerzése azonban még szükséges a megvalósításhoz.

Debrecen felkészült lehet egy HUB létrehozásához, megvan az elegendő tudása, hiszen a Debreceni Egyetem megfelelő tudásbázist biztosítana, s van jó néhány tenni akaró nagyobb, illetve kisebb cég is, akikkel lehetne müködtetni a rendszert. Ami veszélyt jelenthet, hogy ez az országban első számú ilyen jellegü kezdeményezése lenne, $\mathrm{s}$ újdonsága miatt illetve a lokalitása miatt (vidéki térség), a más nagyobb lobbi erővel rendelkező kezdeményezés kapna támogatási keretet, illetve hírnevet. Illetve a network által felállított müködési keretrendszer, talán túlzott korlátokba szorítaná a müködést, kevesebb szabad teret adna a város és az alapítók ötleteinek megvalósításához. Amíg a megvalósítási folyamat el nem kezdődik, addig nehéz tényleges veszélyeit/korlátait elöre látni, hiszen egy élő, 
állandóan formálódó, több évig fennálló rendszer, melyet manapság elöre megtervezni nem igazán lehetséges, jóslatokba meg nem érdemes bocsátkozni.

$\mathrm{Az}$ eredmények és információk alapján a megvalósítást szem elött tartva a jövőre vonatkozóan, érdemes lépésről-lépésre vizsgálni a HUB kialakításának szempontjait. Vizsgálni szükséges még a város potenciálját, a network által készített megvalósíthatósági tanulmány szemszögéből. Az információk beszerzésére, illetve a piac tesztelésére a végleges prototípus megalkotásához, jó alapot adhat egy Delphi konferencia megszervezése, a piac véleményeinek, összegyüjtéséhez, rendszerezéséhez és értékeléséhez. Illetve egy hasonló szemléletü, co-working közösségi munkatér kialakítása (Coworking Közösség és Közösségi Tér 2009). Ezáltal tesztelhető lenne a piac, ami felkészülést adhatna az alapítók számára, akár a kezdeti alapítási nehézségek és az érdektelenségek is áthidalhatóak lennének.

\section{5. ÖSSZEGZÉS}

Összességében, a megvalósíthatósági tanulmány készítésének elő fázisa sikeresen zárult. Az ötlet a megvalósításhoz pozitív visszajelzés kapott mindkét esetben, mindkét esetben egyértelmüen elmondható, hogy az Impact HUB adta lehetőségek kihasználása Debrecen vállalkozói piaca számára szükséges, és jelentős pozitív eredményeket hozhat a vállalkozások működése és a város gazdaságának élénkítés szempontjából. Hiszen Debrecennek már vannak hasonló helyei, vagy közel azonosan müködő terei (inkubátorházak), de mégis a piac véleménye, az hogy ez a rendszer alapvetően mást adhat számukra, mint a már meglévőek. Egyrészt ez köszönhető talán az újszerüségének, vagy annak, hogy ez a rendszer megengedheti azt, amit sokan keresnek, a nemzetközi jelenlét a cég müködésében, hiszen a networknek köszönhetően könnyebben elérhetővé válik számukra. Továbbiakban fontos szem elött tartani, hogy a jelenlegi 2014-2020-as innovációs stratégiai tervezés megfelelő alapot adhat, a hasonló kezdeményezések megvalósítására.

\section{IRODALOMJEGYZÉK}

Coworking Közösség és Közösségi Tér $\quad$ (2009): Múlt. (http://coworking.blog.hu/2009/04/02/mult_19; 2013.07.)

Etkowitz, H. (2002): The Triple Helix of University-Industry-Government Implications for Policy and Evaluation. (http://www.sister.nu/pdf/wp_11.pdf; 2013.07.)

HUB GmbH (2012): Impact HUB kézikönyv Invitation Booklet. (http://www.impacthub.net/; 2013.06.)

Klerkx, L. - Van Mierlo, B. - Leeuwis, C. (2013): Evolution of systems approaches to agricultural innovation: concepts, analysis and interventions (http://www.academia.edu/1569316/Evolution_of_systems_approaches_to_agricultural_innovati on_Concepts_analysis_and_interventions; 2013.07.)

Nemzetgazdasági Minisztérium (2013): Befektetés a jövőbe. Nemzeti Kutatás-fejlesztési és Innovációs Stratégia (2013-2020) (http://www.nih.gov.hu/strategiaalkotas/hirekesemenyek/nemzeti-kfi; 2013.09.) 
Molnár I. - Németh G. (2009): Egyetemi szellemi tulajdon-védelem és ipari kapcsolatok a nyílt innovációs közegben: Open Access vagy monopoljogok? Iparjogvédelmi és Szerzöi Jogi Szemle, Budapest, 4. 114. évfolyam. 5. sz. pp. 5-26.

OECD Background report (2007): National system of innovation in Hungary. http://www.nih.gov.hu/nemzetkozi-tevekenyseg/oecd/oecd-background-report; 2013.09.)

Oláh J. - Hutóczki R. (2012): A Debreceni Egyetem emberi erőforrás tanácsadó szakán végzett hallgatók pályakezdők munkaerőpiaci esélyei Magyarországon. Közgazdász Fórum Romániai Magyar Közgazdász Társaság - Babes Bólyai Tudományegyetem Közgazdaság- és Gazdálkodástudományi Kar közös szakmai közlönye XV. évf. 107. sz. 2012/4. pp. 27-40.

Pakucs J. - Papanek G. ( 2006): Innováció menedzsment kézikönyv. Magyar Innovációs Szövetség, Budapest.

Tactics Project (2012): Cluster Internationalisation Handbook. http://www.reglab.se/klusterutveckling/wp-content/uploads/2012/03/ClusterInternationalization-handbook-the-printed-version.pdf.

Linstone, H. A - Turoff, M. (2002): Introduction. In. Linstone, H. A - Turoff, M. (eds): The Delphi Method: Techniques and Applications. New Jersey Institute of Technology, Electronic Version. (http://is.njit.edu/pubs/delphibook/ch1.html; 2013.07.) 